\title{
Nutrition, Trace Elements
}

National Cancer Institute

\section{Source}

National Cancer Institute. Nutrition, Trace Elements. NCI Thesaurus. Code C15605.

Role of trace elements in cancer causation or prevention and in general health. 